\title{
Synthesis, Characterization, and Antimicrobial and Antispermatogenic Activity of Bismuth(III) and Arsenic(III) Derivatives of Biologically Potent Nitrogen and Sulfur Donor Ligands
}

\author{
Latika Dawara, ${ }^{1}$ S. C. Joshi, ${ }^{2}$ and R. V. Singh ${ }^{1}$ \\ ${ }^{1}$ Centre for Advanced Studies in Chemistry, University of Rajasthan, Jaipur 302004, India \\ ${ }^{2}$ Department of Zoology, University of Rajasthan, Jaipur 302004, India \\ Correspondence should be addressed to R. V. Singh, rvsjpr@hotmail.com
}

Received 7 November 2011; Revised 12 January 2012; Accepted 26 January 2012

Academic Editor: Hakan Arslan

Copyright () 2012 Latika Dawara et al. This is an open access article distributed under the Creative Commons Attribution License, which permits unrestricted use, distribution, and reproduction in any medium, provided the original work is properly cited.

A series of $\mathrm{Bi}(\mathrm{III})$ and $\mathrm{As}(\mathrm{III})$ complexes with two $\mathrm{N}^{n} \mathrm{~S}$ donor ligands, 1-(4-chloro-2-oxo-2H-chromen-3-yl)-methylene)thiosemicarbazide $\left(\mathrm{L}^{1} \mathrm{H}\right)$ and $\mathrm{N}^{\prime}$-[1-(2-oxo-2H-chrome-3yl-ethylidene]-hydrazinecarbodithionic acid benzyl ester ( $\left.\mathrm{L}^{2} \mathrm{H}\right)$ have been synthesized by the reaction of $\mathrm{BiCl}_{3}$ and $\mathrm{Ph}_{3} \mathrm{As}$ with ligands in 1:1 and 1:2 molar ratios. All the synthesized compounds were characterized by elemental analyses, melting point determinations, and a combination of electronic, IR, ${ }^{1} \mathrm{H} \mathrm{NMR},{ }^{13} \mathrm{C}$ NMR spectroscopic techniques, and X-ray diffraction for structure elucidation. In order to evaluate the effect of metal ions upon chelation, both the ligands and their complexes have been screened for their antimicrobial activity against the various pathogenic bacterial and fungal strains. The metal complexes have shown to be more antimicrobial against the microbial species as compared to free ligands. Both the ligands and their corresponding metal complexes have been tested for their antifertility activity in male albino rats. The marked reduction in sperm motility and density resulted in infertility. Significant alterations were found in biochemical parameters of reproductive organs in treated animals as compared to control group. It is concluded that all these effects may finally impair the fertility of male rats.

\section{Introduction}

Interest in coordination chemistry is increasing continuously with the preparation of organic ligands containing a variety of donor groups, and it is multiplied manifold when the ligands have biological importance [1]. The number and diversity of nitrogen and sulfur chelating agents used to prepare new coordination and organometallic compounds have increased rapidly during the past few years [2-4]. Sulfur compounds and their metal complexes have antimicrobial activity and showed a high dependence on their substituents $[5,6]$. Organic compounds containing $-\mathrm{C}_{6} \mathrm{H}_{4} \mathrm{~S}$ moiety are well known for their significant biological activities. The activity may be due to the presence of multi-coordination centers having the ability to form stable chelates with the essential metal ions which the organisms need in their metabolism. Interest in metal complexes of sulfur-nitrogen chelating agents, especially those formed from thiosemicarbazide [7] and S-alkyl/benzyl esters of dithiocarbazic acid has been stimulated by their interesting physicochemical properties and potentially useful pharmacological properties [8].

In the present paper, we describe the synthesis of metal complexes with Schiff bases using microwave-assisted technique. Bismuth compounds have been used in medicine for more than two centuries [9]. Applications have been widespread, due to bismuth's antiseptic, astringent, protective, antacid, antisecretory, and local gastrointestinal properties. Organoarsenicals were the first compounds applied for the successful treatment of syphilis (they have since been replaced by penicillin) and have been used as feed additives in livestock to prevent bacterial and parasitic infections. Organoarsenic(III) compounds are known to be biologically 
active and find applications in various fields. Antimicrobial activities of some arsenic(III) complexes with Schiff bases have been evaluated [10].

The focus of our present communication is on the exploration of the studies on the synthetic, structural, and biological aspects of $\mathrm{Bi}(\mathrm{III})$ and $\mathrm{As}(\mathrm{III})$ complexes of some stereochemical as well as biological interest with monobasic bidentate thiosemicarbazone and hydrazinecarbodithioic acid ligands.

\section{Experimental}

2.1. Materials and Methods. $\mathrm{BiCl}_{3}$ and $\mathrm{Ph}_{3} \mathrm{As}$ as well as 3 -acetylcoumarin and 4-hydroxycoumarin were purchased from Alfa Aesar and used as such. All the chemicals and solvents were dried and purified by standard methods. The reactions were carried out under strictly anhydrous conditions. Molecular weights were determined by the Rast camphor method. Chlorine was estimated by Volhard's method. Bismuth was estimated complexometrically. Arsenic was estimated iodimetrically. Nitrogen was estimated by the Kjeldahl method, and sulfur was estimated by the Messenger method [11]. Carbon and hydrogen analyses were performed at the CDRI, Lucknow, India. The electronic spectra were recorded on a Varian-Cary/2390 spectrophotometer at RSIC, IIT, Chennai, India. Infrared spectra of the ligands and their complexes were recorded on a Nicolet Megna FTIR550 spectrophotometer using $\mathrm{KBr}$ pellets. ${ }^{1} \mathrm{H}$ and ${ }^{13} \mathrm{C}$ NMR spectra were recorded on a JEOL-AL-300 FT NMR spectrometer in DMSO-d6. X-ray powder diffractogram of a representative compound was obtained on a Philip Model PW1840 automatic diffractogram using $\mathrm{Cu}(\mathrm{K} \alpha)$ target with $\mathrm{Mg}$ filter. The wavelength used was $1.540598 \mathrm{~A}^{\circ}$.

2.2. Preparation of the Ligands. Two different routes, microwave-assisted synthesis and conventional method, were employed for the synthesis of the ligands (see Scheme 1).

3-Formyl-4-chlorocoumarin. Phosphorus oxychloride (10 $\mathrm{mL}$ ) was added dropwise to a solution of dimethylformamide (DMF) $(20 \mathrm{~mL})$ keeping the temperature below $5^{\circ} \mathrm{C}$. Solution of 4-hydroxycoumarin $(4.0 \mathrm{~g})$ in DMF $(10 \mathrm{~mL})$ was then gradually added to the mixture with constant stirring and maintaining the temperature of the reaction mixture below $5^{\circ} \mathrm{C}$. The reaction mixture was then allowed to stand at room temperature for $2 \mathrm{~h}$ and then heated on a steam bath for $1 \mathrm{~h}$. After cooling, the reaction mixture was poured onto crushed ice and neutralized with sodium carbonate. A solid product was immediately formed which was crystallized from ethanol to give a yellow solid (80\%), MP $115^{\circ} \mathrm{C}$ [12].

2.2.1. Microwave-Assisted Synthesis. The ligands were prepared by the condensation of 3-formyl-4-chlorocoumarin with thiosemicarbazide and 3-acetyl coumarin with Sbenzyldithiocarbazate in the presence of sodium acetate. The reaction mixture was irradiated in the microwave oven by taking $2-3 \mathrm{~mL}$ solvent. The reactions were completed in a short period $(5-7 \mathrm{~min})$. The resulting precipitate was then recrystallized with alcohol and dried under vacuum. These were characterized and analysed before use. Elemental analyses (N and $\mathrm{S}$ ) were conducted using the methods mentioned above, and their results were found to be in good agreement with the calculated values. The structures of the ligands have been shown in Figure 1 (see Scheme 2).

The above ligands were also synthesized by a thermal method, where instead of few drops of alcohol the starting materials of the ligands were dissolved in $\sim 100 \mathrm{~mL}$ of alcohol and the contents were refluxed for nearly 4 to $5 \mathrm{~h}$. The solution was then concentrated under reduced pressure, which on cooling gave crystalline precipitates. These were recrystallized twice in alcohol.

\subsection{Preparation of the Metal Complexes}

2.3.1. Synthesis of the Bi(III) Complexes. For the synthesis of the complexes, $\mathrm{BiCl}_{3}$ and sodium salt of the ligands (prepared by adding the corresponding weight of sodium metal to the ligand) in $5 \mathrm{~mL}$ of dry methanol in $1: 1$ and $1: 2$ molar ratios were irradiated inside a microwave oven for about 5-8 min. The products were recovered from the microwave oven and dissolved in few $\mathrm{mL}$ of dry methanol. The white precipitate of sodium chloride formed during the course of the reaction was removed by filtration, and the filtrate was dried under reduced pressure. The resulting product was repeatedly washed with petroleum ether and then finally dried at $40-60^{\circ} \mathrm{C} / 0.5 \mathrm{mmHg}$ for $3-4 \mathrm{~h}$. The purity was further checked by thin layer chromatography using silica gel-G.

Chlorobismuth(III) complexes were also synthesized by the thermal method. The reaction mixtures were heated under reflux for $13-17 \mathrm{~h}$ and filtered to remove $\mathrm{NaCl}$, and the solvent was removed by the same procedure mentioned above, which was adopted to get the complexes.

2.3.2. Synthesis of Arsenic(III) Complexes. These complexes were prepared by the reaction of triphenylarsine in dry benzene with equimolar and bimolar amounts of the ligand which was previously dissolved in few $\mathrm{mL}$ of benzene. The reaction mixture was heated under reflux for $10-15 \mathrm{~h}$. The complexes were repeatedly washed with dry n-hexane and dry pet-ether and dried at $40-60^{\circ} / 0.5 \mathrm{~mm}$ of $\mathrm{Hg}$ pressure for $3-4 \mathrm{~h}$. The purity was further checked by TLC using silica gel-G. The physico-chemical properties and analytical data of these complexes are listed below.

1-(4-Chloro-2-oxo-2H-chromen-3-yl)-methylene)thiosemicarbazide $\left(L^{1} H\right) .\left(\mathrm{C}_{11} \mathrm{H}_{8} \mathrm{ClN}_{3} \mathrm{O}_{2} \mathrm{~S}\right)$ colour, brown, mol. wt., 281.35 (281.71), M. P., $128^{\circ} \mathrm{C}, \mathrm{C}, 45.23$ (46.90), H, 2.09 (3.52), N, 14.33 (14.92), S, 11.13 (11.80), yield 82\% T $(88 \% \mathrm{MW})$.

$\mathbf{N}^{\prime}$-[1-(2-oxo-2H-chrome-3-yl-ethylidene]hydrazinecarbthionicacid benzyl ester $\left(L^{2} \mathrm{H}\right) .\left(\mathrm{C}_{19} \mathrm{H}_{16} \mathrm{~N}_{2} \mathrm{O}_{2} \mathrm{~S}_{2}\right)$ colour, red, mol. wt., 366.85 (368.47), MP, $155^{\circ} \mathrm{C}, \mathrm{C}, 60.91$ (61.93), $\mathrm{H}, 4.19$ (4.38), N, 6.56 (7.60), S, 16.54 (17.40), yield 77\%T $(86 \% \mathrm{MW})$. 


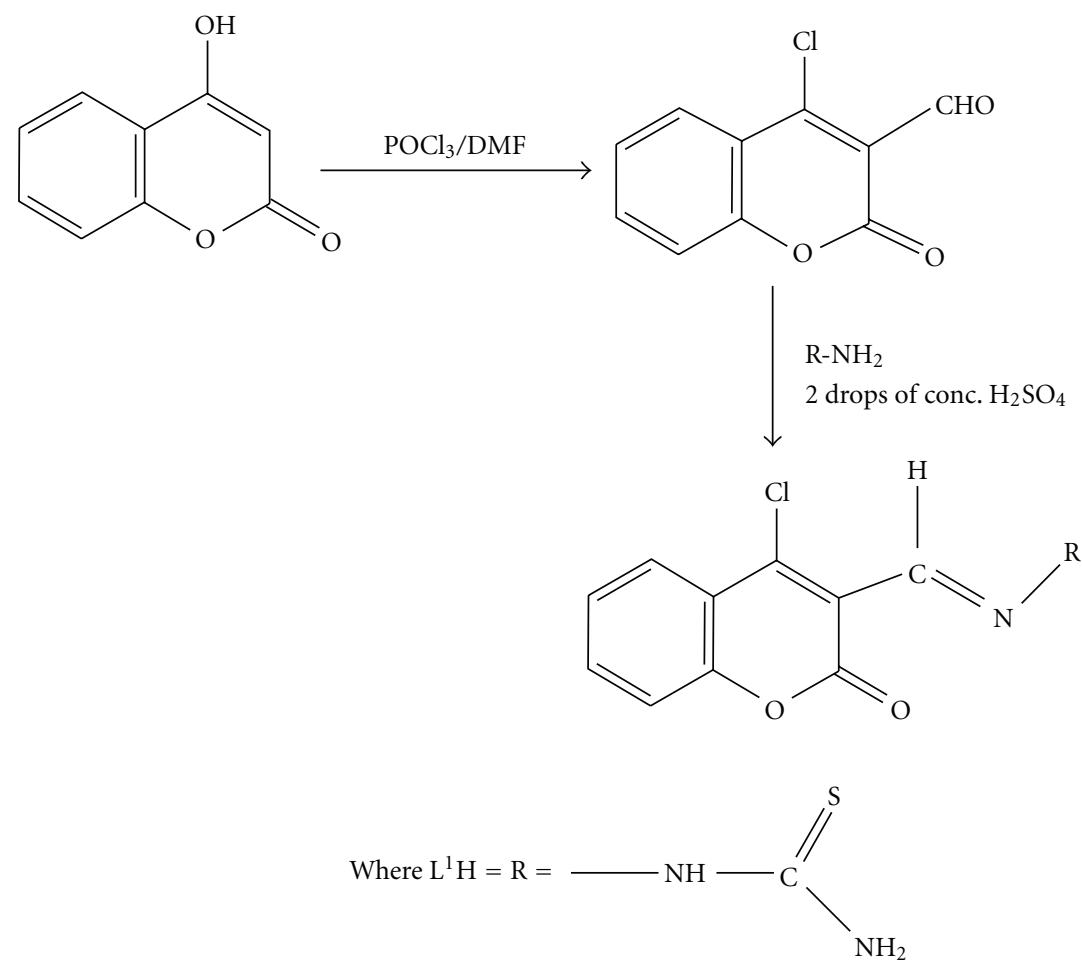

SCHEME 1

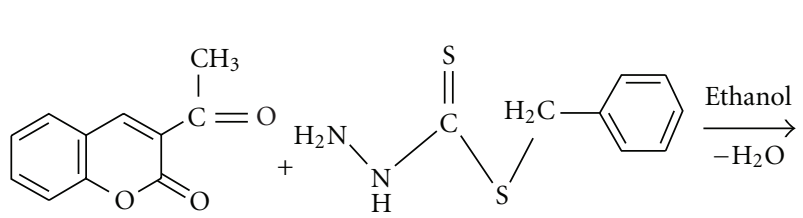<smiles>C/C(=N\NC(=S)SCc1ccccc1)c1cc2ccccc2oc1=O</smiles><smiles>[C]=[V]</smiles><smiles>C/C(=N/N=C(S)SCc1ccccc1)c1cc2ccccc2oc1=O</smiles>

Scheme 2: Synthesis of N'-[1-(2-oxo-2H-, chrome-3yl-ethylidene]-hydrazinecarbodithionic acid benzyl ester $\left(\mathrm{L}^{2} \mathrm{H}\right)$.

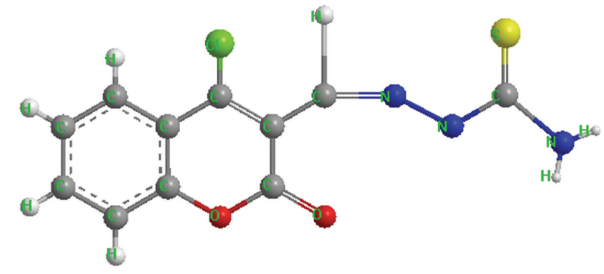

$\left(\mathrm{L}^{1} \mathrm{H}\right)$

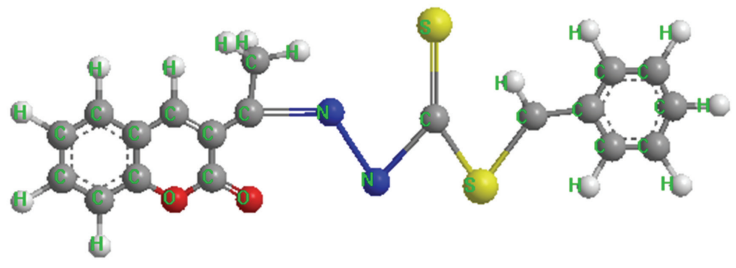

$\left(\mathrm{L}^{2} \mathrm{H}\right)$

(b)

FIgURE 1: 3D molecular structures of the ligands. 
Bismuth(III) Complexes with $L^{1} H$ and $L^{2} H$ (Monofunctional Bidentate). $\left[\mathrm{Cl}_{2} \mathrm{Bi}\left(\mathrm{L}^{1}\right)\right]$, colour, dark brown, mol. wt., 558.14 (560.6), MP, $150^{\circ} \mathrm{C}, \mathrm{C}, 22.56$ (23.57), H, 1.18 (1.26), N, 6.56 (7.50), Cl, 17.25 (18.97), Bi, 36.99 (37.28), yield 75\% $\mathrm{MW})$.

$\left[\mathrm{ClBi}\left(\mathrm{L}^{1}\right)_{2}\right]$, colour, brown, mol.wt. 782.56 (785.44), MP, $183^{\circ} \mathrm{C}, \mathrm{C}, 34.25$ (35.17), H, 2.00 (2.18), N, 9.12 (10.70), Cl, 8.23 (9.03), Bi, 25.63 (26.61), yield 73\% T (90\% MW).

$\left.\mathrm{Cl}_{2} \mathrm{Bi}\left(\mathrm{L}^{2}\right)\right]$, colour, light green, mol. wt., 645.32 (647.35), MP, $105^{\circ} \mathrm{C}, \mathrm{C}, 33.59$ (35.25), H, 1.99 (2.34), N, 3.56 (4.33), S, 8.65 (9.91) Bi, 31.99 (32.28), yield 78\%T (91\% MW).

$\left[\mathrm{ClBi}\left(\mathrm{L}^{2}\right)_{2}\right]$, colour, light yellow, mol.wt. 978.25 (979.36), MP, $210^{\circ} \mathrm{C}, \mathrm{C}, 45.25$ (46.40), H, 2.85 (3.09), N, 4.82 (5.72), S, 12.36 (13.10) Bi, 20.63 (21.34), yield 77\% T (90\% MW).

Arsenic(III) Complexes with $L^{1} H$ and $L^{2} H$ (Monofunctional Bidentate). $\mathrm{Ph}_{2} \mathrm{As}\left(\mathrm{L}^{1}\right)$ colour, yellow, mol. wt. 508.45 (509.84), MP, $96^{\circ} \mathrm{C}, \mathrm{C}, 53.78$ (54.18), H, 3.25 (3.36), N, 7.95 (8.24), S, 6.00.26 (6.29) As, 13.99 (14.70), yield 67\%.

$\mathrm{PhAs}\left(\mathrm{L}^{1}\right)_{2}$, colour, orange, mol.wt. 612.65 (613.45), MP, $116^{\circ} \mathrm{C}, \mathrm{C}, 46.78$ (47.14), H, 2.25 (2.68), N, 9.12 (11.78), S, 7.56 (8.99) As, 9.97 (10.50), yield 68\%.

$\mathrm{Ph}_{2} \mathrm{As}\left(\mathrm{L}^{2}\right)$ colour, orange, mol. wt. 595.46 (596.59), MP, $166^{\circ} \mathrm{C}, \mathrm{C}, 61.71$ (62.41), H, 3.96 (4.22), N, 4.12 (4.70), S, 9.26 (10.75) As, 11.99 (12.56), yield 69\%.

PhAs $\left(\mathrm{L}^{2}\right)_{2}$, colour, red, mol.wt. 885.25 (886.95), MP, $174^{\circ} \mathrm{C}, \mathrm{C}, 58.32$ (59.58), H, 2.89 (3.98), N, 5.62 (6.32), S, 13.21 (14.46) As, 7.97 (8.45), yield 70\%.

\section{Biological Assay}

All the compounds were evaluated for their antimicrobial properties. MIC was recorded as minimum concentration which inhibits the growth of microorganism. The results obtained were compared with those of the standard drug streptomycin for bacteria and bavistin for fungi. The microorganisms used were Escherichia coli (ATCC25922), Bacillus subtilis (ATCC6633), Fusarium oxysporum (ATCC7808) and Rhizopus nigricans (ATCC6227b). Both ligands and their corresponding metal complexes have been tested in vivo for their antifertility activity in male albino rats.

\subsection{In Vitro Study}

3.1.1. Antibacterial Screening. The newly prepared compounds were screened for their antibacterial activity against Escherichia coli (ATCC25922) and Bacillus subtilis (ATCC6633) by paper disc plate method [13]. Each compound was dissolved in DMSO, and solutions of the concentrations (500 and $1000 \mathrm{ppm}$ ) were prepared separately. Paper discs of Whatman filter paper (no. 42) of uniform diameter $(5 \mathrm{~mm})$ were cut and sterilized in an autoclave. The paper discs soaked in the desired concentration of the complex solutions were placed aseptically in the petri dishes containing nutrient agar media (agar $20 \mathrm{~g}+$ beef extract $3 \mathrm{~g}$ + peptone $5 \mathrm{~g}$ ) seeded with Escherichia coli (ATCC25922) and Bacillus subtilis (ATCC6633) separately. The petri dishes were incubated at $37^{\circ} \mathrm{C}$, and the inhibition zones were recorded after $24 \mathrm{~h}$ of incubation. The antibacterial activity of standard antibiotic streptomycin was also recorded using the same procedure. The medium with DMSO as a solvent was used as a negative control. The experiments were performed in triplicates. The \% activity index for the complex was calculated by the formula as follows:

$$
\begin{aligned}
& \% \text { Activity Index } \\
& =\frac{\text { zone of inhibition by test compound (diameter) } \times 100}{\text { zone of inhibition by standard (diameter) }} .
\end{aligned}
$$

3.1.2. Antifungal Screening. The antifungal activities of the standard fungicide (Bavistin), ligands, and complexes were tested for their effect on the growth of microbial cultures and studied for their interaction with Fusarium oxysporum (ATCC7808) and Rhizopus nigricans (ATCC6227b) using Czapek's agar medium [14] having the composition, glucose $20 \mathrm{~g}$, starch $20 \mathrm{~g}$, agar-agar $20 \mathrm{~g}$, and distilled water $1000 \mathrm{~mL}$. To this medium was added requisite amount of the compounds after being dissolved in methanol so as to get the certain concentrations (100 and $200 \mathrm{ppm}$ ). The medium then was poured into Petri Plates, and the spores of fungi were placed on the medium with the help of inoculum's needle. These Petri Plates were wrapped in polythene bags containing a few drops of alcohol and were placed in an incubator at $\pm 30^{\circ} \mathrm{C}$. The controls were also run, and three replicates were used in each case. The linear growth of the fungus was recorded by measuring the diameter of the fungal colony after $96 \mathrm{~h}$ and the percentage inhibition was calculated by the equation

$$
\% \text { of inhibition }=\frac{C-T}{C} \times 100,
$$

where $C$ and $T$ are the diameters of the fungal colony in the control and the test plates, respectively.

\subsubsection{Determination of Minimum Inhibitory Concentration} (MIC). The minimum inhibitory concentration (MIC) is the lowest concentration of the antimicrobial agent that prevents the development of viable growth after overnight incubation [15]. The determination of the MIC involves a semiquantitative test procedure, which gives an approximation to the least concentration of an antimicrobial needed to prevent microbial growth. The minimum inhibitory concentration was determined by microbroth dilution method [16]. Inoculum of the overnight culture was prepared. In a series of tubes, $1 \mathrm{~mL}$ each of complex solution with different concentrations was taken and $0.4 \mathrm{~mL}$ of the inoculum was added to each tube. Further $3.5 \mathrm{~mL}$ of the sterile water was added to each of the test tubes. These test tubes were incubated for $18 \mathrm{~h}$ and observed for the presence of turbidity. The absorbance of the suspension of the inoculum was observed with spectrophotometer at $555 \mathrm{~nm}$. The end result of the test was the minimum concentration of the antimicrobial agent (test materials) which gave a clear solution, that is, no visual growth $[17,18]$. 


\subsection{In Vivo Study}

3.2.1. Antifertility Activity. The activity of the synthetic products towards the biological systems is an important feature of the current research, and the Schiff base metal complexes play a significant role in this direction. In view of such potential interest in these biologically active compounds, the antifertility activity of some selected compounds has been studied on male albino rats. Proven-fertile male albino rats of the Wistar strain, weighing 190-200 g (90-100 days old), were used. They were housed in clean, polypropylene cages and maintained under standard conditions $(12 \mathrm{~h}$ light $/ 12 \mathrm{~h}$ dark; $20 \pm 5^{\circ} \mathrm{C} ; 35-60 \%$ relative humidity). Rat feed (Ashirwad Industries Ltd., Chandigarh, India) and water were provided ad libitum. Animals were divided into seven groups of six animals each. Group A served as a vehicle (olive oil) treated control. In the groups Band $C$, the ligands $L^{1} \mathrm{H}$ and $\mathrm{L}^{2} \mathrm{H}$, and in animals of groups $\mathrm{D}, \mathrm{E}, \mathrm{F}$, and $\mathrm{G}$ the compounds $\left[\mathrm{Ph}_{2} \mathrm{As}\left(\mathrm{L}^{1}\right)\right],\left[\operatorname{PhAs}\left(\mathrm{L}^{1}\right)_{2}\right]$, $\left[\mathrm{Cl}_{2} \mathrm{Bi}\left(\mathrm{L}^{2}\right)\right]$ and $\left[\mathrm{ClBi}\left(\mathrm{L}^{2}\right)_{2}\right](30 \mathrm{mg} / \mathrm{kg}$ b.wt $)$ suspended in olive oil were given orally for a period of 60 days. At the end of experiment, all the animals were screened for fertility test and autopsied. The reproductive organs were removed, washed with distilled water, dried weight, and processed for biochemical examination. Sperm mobility in cauda epididymis and sperm density in testes and cauda epididymis were assessed. The protein, sialic acid, glycogen, acid and alkaline phosphatase of testes, and serum testosterone were determined by standard laboratory techniques. Results were analysed statistically using student's $t$-test.

\section{Results and Discussion}

The elemental analysis and spectral data suggested the formation of the ligands $\left(\mathrm{L}^{1} \mathrm{H}\right.$ and $\left.\mathrm{L}^{2} \mathrm{H}\right)$ and their complexes of the type $\left[\mathrm{Cl}_{2} \mathrm{Bi}\left(\mathrm{L}^{1}\right)\right],\left[\mathrm{ClBi}\left(\mathrm{L}^{1}\right)_{2}\right],\left[\mathrm{Cl}_{2} \mathrm{Bi}\left(\mathrm{L}^{2}\right)\right],\left[\mathrm{ClBi}\left(\mathrm{L}^{2}\right)_{2}\right]$, $\left[\mathrm{Ph}_{2} \mathrm{As}\left(\mathrm{L}^{1}\right)\right],\left[\operatorname{PhAs}\left(\mathrm{L}^{1}\right)_{2}\right],\left[\mathrm{Ph}_{2} \mathrm{As}\left(\mathrm{L}^{2}\right)\right]$, and $\left[\operatorname{PhAs}\left(\mathrm{L}^{2}\right)_{2}\right]$. The resulting complexes are colored solid, which were found to be soluble in DMF and DMSO. Molecular weight determinations showed that they are monomeric in nature. The molar conductances of $10^{-3} \mathrm{M}$ solutions of the complexes in dry DMF lie in the $12-15 \mathrm{ohm}^{-1} \mathrm{~cm}^{2} \mathrm{~mol}^{-1}$ range, indicating that they are nonelectrolytes.

4.1. UV Spectra. The electronic spectra of the ligands show a band due to the $>\mathrm{C}=\mathrm{N}$ chromophore observed at $365 \mathrm{~nm}$ that shifts to the lower wavelength region in the spectra of the complexes. Such a shift in the $n-\pi^{*}$ band is probably due to the donation of the lone pair of electrons by the nitrogen of the ligand to the central metal atom. Two bands at 319320 and $298-300 \mathrm{~nm}$ assigned to $\pi-\pi^{*}$ transitions, within the benzene and coumarin rings and azomethine linkage also show some shifting in their position due to bond formation.

4.2. IR Spectra. The IR spectra of the free ligands $\mathrm{L}^{1} \mathrm{H}$ and $\mathrm{L}^{2} \mathrm{H}$ display absorption bands at $3150-3250,1630-1635$, and $1050-1080 \mathrm{~cm}^{-1}$ assigned to $(-\mathrm{NH}),(>\mathrm{C}=\mathrm{N})$, and $(>\mathrm{C}=\mathrm{S})$, respectively. The bands at ca. $1735 \mathrm{~cm}^{-1}$ due to $(>\mathrm{C}=\mathrm{O})$ of lactone moiety of the ligands remain almost unchanged in the complexes indicating their non-involvement in complexation. The broad band, due to $(-\mathrm{NH})$ vibrations, disappears in the spectra of the complexes, indicating the deprotonation of this group on coordination with the metal atom. The marked shift $\left(10-20 \mathrm{~cm}^{-1}\right)$ of $(>\mathrm{C}=\mathrm{N})$ band observed in all the complexes indicates the involvement of azomethine nitrogen upon complexation. The band due to $(>\mathrm{C}=\mathrm{S})$ is shifted towards lower frequencies in the complexes indicating coordination of sulfur to the central metal atom. The spectra of the free ligands display two sharp bands at 3340-3500 and $3350-3490 \mathrm{~cm}^{-1}$ due to asym. and sym. vibrations of $\mathrm{NH}_{2}$ group, respectively, which remain at almost the same positions in the spectra of the complexes, suggesting that the $\mathrm{NH}_{2}$ group is not involved in chelation. Some new bands observed in the regions $439-442$ and $422-425 \mathrm{~cm}^{-1}$ for $v$ (As $\leftarrow \mathrm{N}), v($ As-S), respectively. The band in $450-$ $470 \mathrm{~cm}^{-1}$ range may be assigned to $\nu(\mathrm{As}-\mathrm{Ph})$ vibrations in the respective complexes.

4.3. ${ }^{1} \mathrm{H} N M R$ and ${ }^{13} \mathrm{C}$ NMR Spectra. Further evidence for the coordinating mode of the ligands was obtained from ${ }^{1} \mathrm{H}$ NMR spectra. The ${ }^{1} \mathrm{H}$ NMR spectra of the ligands recorded in DMSO- $\mathrm{d}_{6}$ exhibit a broad peak at $\delta 8.59-8.30 \mathrm{ppm}$ due to $-\mathrm{NH}$ proton. The $-\mathrm{NH}$ proton signal of the ligands disappears in the complexes. The absence of this signal in these complexes suggests that this proton has been lost via thioenolization of $>\mathrm{C}=\mathrm{S}$ group and coordination of sulfur to the metal atoms, respectively, has taken place. The $>\mathrm{CH}=\mathrm{N}$ proton moves downfield in the complexes in comparison with its original positions in the ligands due to coordination of $>\mathrm{C}=\mathrm{N}$ to the metal atom. The ${ }^{1} \mathrm{H}$ NMR spectrum of the ligand $\left(\mathrm{L}^{2} \mathrm{H}\right)$ exhibits $-\mathrm{CH}_{2}$ proton signals at $\delta 4.15$ $4.16 \mathrm{ppm}$, and aromatic protn signals at $\delta 6.38-7.50 \mathrm{ppm}$ and these remain at the same position in the spectra of the metal complexes. In the case of ${ }^{13} \mathrm{C}$ NMR spectra, the considerable shifts in the position of the carbon atoms attached to the different participating groups clearly indicate the bonding of azomethine nitrogen to the metal atom. The signal due to lactone $>\mathrm{C}=\mathrm{O}$ carbon atoms remains almost same position in the ${ }^{13} \mathrm{C}$ NMR spectra of the metal complexes while mark shifts in the position of the carbon atoms attached to the sulfur atom shows that proton is lost via thioenolization. Spectral data of the ligands and their metal complexes are given below.

$L^{1} H$. IR $\left(\mathrm{KBr}, \quad v \mathrm{~cm}^{-1}\right): \quad 3150 \mathrm{~cm}^{-1}(-\mathrm{NH} \quad$ stretching), $1635 \mathrm{~cm}^{-1} \quad(>\mathrm{C}=\mathrm{N}), \quad 1080 \mathrm{~cm}^{-1} \quad(>\mathrm{C}=\mathrm{S}), \quad 1735 \mathrm{~cm}^{-1}$, $(>\mathrm{C}=\mathrm{O}) ;{ }^{1} \mathrm{H}$ NMR $\left(600 \mathrm{MHz}, \mathrm{DMSO}_{-} \mathrm{d}_{6}, \delta \mathrm{ppm}\right), \delta$ $8.69 \mathrm{ppm}(1 \mathrm{H},-\mathrm{NH}), \delta 6.70 \mathrm{ppm}(1 \mathrm{H}, \mathrm{HC}=\mathrm{N}) \delta 3.46 \mathrm{ppm}$ $\left(-\mathrm{NH}_{2}\right), \delta 6.72-8.15 \mathrm{ppm}(\mathrm{ArH}) ;{ }^{13} \mathrm{C}$ NMR: $165.65(>\mathrm{C}=\mathrm{N})$, $170.86(>\mathrm{C}=\mathrm{S})$.

$L^{2} H$. IR $\left(\mathrm{KBr}, \quad v \mathrm{~cm}^{-1}\right): 3250 \mathrm{~cm}^{-1} \quad(-\mathrm{NH}$ stretching), $1622 \mathrm{~cm}^{-1}(>\mathrm{C}=\mathrm{N}), 1050 \mathrm{~cm}^{-1}(>\mathrm{C}=\mathrm{S}), 1735 \mathrm{~cm}^{-1}(>\mathrm{C}=\mathrm{O})$; ${ }^{1} \mathrm{H}$ NMR $\left(600 \mathrm{MHz}\right.$, DMSO-d $\left.\mathrm{d}_{6}, \delta \mathrm{ppm}\right): \delta 8.30 \mathrm{ppm}(1 \mathrm{H},-$ $\mathrm{NH}), \delta 4.15 \mathrm{ppm}\left(-\mathrm{S}-\mathrm{CH}_{2}\right), \delta 7.50-6.38 \mathrm{ppm}(\mathrm{ArH}) ;{ }^{13} \mathrm{C}$ NMR: $166.55(>\mathrm{C}=\mathrm{N}), 172.66(>\mathrm{C}=\mathrm{S})$. 
$\left[\mathrm{Cl}_{2} \mathrm{Bi}\left(\mathrm{L}^{1}\right)\right]$. IR $\left(\mathrm{KBr}, \quad v \mathrm{~cm}^{-1}\right): 1645 \mathrm{~cm}^{-1} \quad(>\mathrm{C}=\mathrm{N})$, $1735 \mathrm{~cm}^{-1}(>\mathrm{C}=\mathrm{O}) ;{ }^{1} \mathrm{H}$ NMR $\left(600 \mathrm{MHz}, \mathrm{DMSO}-\mathrm{d}_{6}, \delta \mathrm{ppm}\right)$ : $\delta \quad 6.80 \mathrm{ppm}(1 \mathrm{H}, \quad \mathrm{HC}=\mathrm{N}) \delta \quad 3.47 \mathrm{ppm} \quad\left(-\mathrm{NH}_{2}\right), \delta \quad 6.73-$ 8.09 ppm (ArH); ${ }^{13} \mathrm{C}$ NMR: $169.20(>\mathrm{C}=\mathrm{N}), 162.56(>\mathrm{C}=\mathrm{S})$.

[ClBi $\left.\left(L^{1}\right)_{2}\right]$. IR $\quad\left(\mathrm{KBr}, v \mathrm{~cm}^{-1}\right): \quad 1643 \mathrm{~cm}^{-1} \quad(>\mathrm{C}=\mathrm{N})$, $1735 \mathrm{~cm}^{-1}(>\mathrm{C}=\mathrm{O}) ;{ }^{1} \mathrm{H} \mathrm{NMR}\left(600 \mathrm{MHz}, \mathrm{DMSO}_{-} \mathrm{d}_{6}, \delta \mathrm{ppm}\right)$ : $\delta \quad 6.90 \mathrm{ppm}(1 \mathrm{H}, \mathrm{HC}=\mathrm{N}) \quad \delta 3.43 \mathrm{ppm}\left(-\mathrm{NH}_{2}\right), \delta 6.70-$ 8.10 ppm (ArH); ${ }^{13} \mathrm{C}$ NMR: $170.40(>\mathrm{C}=\mathrm{N}), 160.80(>\mathrm{C}=\mathrm{S})$.

$\left[C l_{2} \mathrm{Bi}\left(\mathrm{L}^{2}\right)\right]:$ IR $\quad\left(\mathrm{KBr}, v \mathrm{~cm}^{-1}\right): \quad 1628 \mathrm{~cm}^{-1} \quad(>\mathrm{C}=\mathrm{N})$, $1735 \mathrm{~cm}^{-1} \quad(>\mathrm{C}=\mathrm{O}) ;{ }^{1} \mathrm{H} \quad \mathrm{NMR} \quad\left(600 \mathrm{MHz}, \quad \mathrm{DMSO}-\mathrm{d}_{6}\right.$, $\delta \mathrm{ppm}): \delta 3.41 \mathrm{ppm}\left(-\mathrm{NH}_{2}\right), \delta \quad 4.15 \mathrm{ppm}\left(-\mathrm{S}-\mathrm{CH}_{2}\right), \delta$ 6.73-8.09 ppm (ArH); ${ }^{13} \mathrm{C}$ NMR: $168.10(>\mathrm{C}=\mathrm{N}), 161.66$ $(>\mathrm{C}=\mathrm{S})$.

[ClBi $\left.\left(L^{2}\right)_{2}\right]$. IR $\quad\left(\mathrm{KBr}, v \mathrm{~cm}^{-1}\right): \quad 1630 \mathrm{~cm}^{-1} \quad(>\mathrm{C}=\mathrm{N})$, $1735 \mathrm{~cm}^{-1} \quad(>\mathrm{C}=\mathrm{O}) ;{ }^{1} \mathrm{H} \quad \mathrm{NMR} \quad\left(600 \mathrm{MHz}, \quad\right.$ DMSO-d $\mathrm{d}_{6}$, $\delta \mathrm{ppm}): \delta 3.42 \mathrm{ppm}\left(-\mathrm{NH}_{2}\right), \delta 4.16 \mathrm{ppm}\left(-\mathrm{S}-\mathrm{CH}_{2}\right), \delta$ 6.70-8.00 ppm (ArH); ${ }^{13} \mathrm{C}$ NMR: $167.10(>\mathrm{C}=\mathrm{N}), 160.86$ $(>\mathrm{C}=\mathrm{S})$.

$\left[P h_{2} A s\left(L^{1}\right)\right]$. IR $\quad\left(\mathrm{KBr}, v \mathrm{~cm}^{-1}\right): \quad 1625 \mathrm{~cm}^{-1} \quad(>\mathrm{C}=\mathrm{N})$, $1735 \mathrm{~cm}^{-1}$ (>C=O), $438 \mathrm{~cm}^{-1}$ (As-S), $423 \mathrm{~cm}^{-1}($ As $\leftarrow \mathrm{N})$; ${ }^{1} \mathrm{H}$ NMR $\left(600 \mathrm{MHz}, \mathrm{DMSO}-\mathrm{d}_{6}, \delta \mathrm{ppm}\right): \delta 6.90 \mathrm{ppm}(1 \mathrm{H}$, $\mathrm{HC}=\mathrm{N}) \delta 3.45 \mathrm{ppm}\left(-\mathrm{NH}_{2}\right), \delta \quad 6.35-8.23 \mathrm{ppm}(\mathrm{ArH}) ;{ }^{13} \mathrm{C}$ NMR: $160.10(>\mathrm{C}=\mathrm{N}) 162.50(>\mathrm{C}=\mathrm{S})$.

$\left[\operatorname{PhAs}\left(L^{1}\right)_{2}\right]$. IR $\left(\mathrm{KBr}, \quad v \mathrm{~cm}^{-1}\right): 1628 \mathrm{Cm}^{-1} \quad(>\mathrm{C}=\mathrm{N})$, $1735 \mathrm{~cm}^{-1}(>\mathrm{C}=\mathrm{O}), 439 \mathrm{~cm}^{-1}($ As-S $), 422 \mathrm{~cm}^{-1}($ As $\leftarrow \mathrm{N})$; ${ }^{1} \mathrm{H}$ NMR $\left(600 \mathrm{MHz}, \mathrm{DMSO}-\mathrm{d}_{6}, \delta \mathrm{ppm}\right): \delta 6.80 \mathrm{ppm}(1 \mathrm{H}$, $\mathrm{HC}=\mathrm{N}) \delta 3.43 \mathrm{ppm}\left(-\mathrm{NH}_{2}\right), \delta 6.89-8.36(\mathrm{ArH}) ;{ }^{13} \mathrm{C} \mathrm{NMR}$ : $161.10(>\mathrm{C}=\mathrm{N}), 160.00(>\mathrm{C}=\mathrm{S})$.

$\left[P h_{2} A s\left(L^{2}\right)\right]$. IR $\quad\left(\mathrm{KBr}, v \mathrm{~cm}^{-1}\right): 1615 \quad \mathrm{Cm}^{-1} \quad(>\mathrm{C}=\mathrm{N})$, $1735 \mathrm{~cm}^{-1}$ (>C=O), $440 \mathrm{~cm}^{-1}$ (As-S), $422 \mathrm{~cm}^{-1}($ As $\leftarrow \mathrm{N})$; ${ }^{1} \mathrm{H}$ NMR (600 MHz, DMSO-d $\left.6, \delta \mathrm{ppm}\right): \delta 3.41 \mathrm{ppm}$ $\left.\left(-\mathrm{NH}_{2}\right), \delta 4.16 \mathrm{ppm}\left(-\mathrm{S}-\mathrm{CH}_{2}\right), \delta 6.50-8.00 \mathrm{ppm} \mathrm{ArH}\right) ;{ }^{13} \mathrm{C}$ NMR: $159.30(>\mathrm{C}=\mathrm{N}), 162.86(>\mathrm{C}=\mathrm{S})$.

[PhAs $\left.\left(L^{2}\right)_{2}\right]$. IR $\quad\left(\mathrm{KBr}, v \mathrm{~cm}^{-1}\right): \quad 1610 \mathrm{~cm}^{-1} \quad(>\mathrm{C}=\mathrm{N})$, $1735 \mathrm{~cm}^{-1}(>\mathrm{C}=\mathrm{O}), 441 \mathrm{~cm}^{-1}$ (As-S), $420 \mathrm{~cm}^{-1}($ As $\leftarrow \mathrm{N})$; ${ }^{1} \mathrm{H}$ NMR $\left(600 \mathrm{MHz}, \mathrm{DMSO}-\mathrm{d}_{6}, \delta \mathrm{ppm}\right): \delta 3.40 \mathrm{ppm}\left(-\mathrm{NH}_{2}\right)$, $\delta 4.15 \mathrm{ppm}\left(-\mathrm{S}-\mathrm{CH}_{2}\right), \delta$ 6.80-8.30 ArH); ${ }^{13} \mathrm{C}$ NMR: 158.70 $(>\mathrm{C}=\mathrm{N}), 160.46(>\mathrm{C}=\mathrm{S})$.

4.4. X-Ray Structure Determination. The possible lattice dynamics of the finely powdered product $\left[\mathrm{ClBi}\left(\mathrm{L}^{1}\right)_{2}\right]$ has been deduced on the basis of X-ray powder diffraction studies. The observed interplanar spacing values (" $d$ " in $\AA$ ) have been measured from the diffractogram of the compound, and the Miller indices $h, k$, and $l$ have been assigned to each $d$ value and 2-Theta angles are reported. The results show that the compound belongs to "orthorhombic" crystal system having unit cell parameters as $a=12.2578$, $b=18.2154, c=8.359$, maximum deviation of 2theta $=0.028$ and alpha $=90$, beta $=90$, gamma $=90$ at the wavelength $=1.540598$.

On the basis of the above discussion, the structures shown in Figures 2 and 3 have been proposed for the complexes.

\section{Biological Results and Discussion}

The results of antimicrobial activity are shown in Figures 3 and 4 . Both the ligands and their metal complexes were sensitive against all the fungal and bacterial strains. The antimicrobial screening data indicate that the metal complexes are more potent antimicrobial agents than the free ligands.

MIC values for the ligands and their complexes are shown in Figure 5. Minimum inhibitory concentration of the ligands and their metal complexes was determined against four tested strains. Compounds $\left[\mathrm{ClBi}\left(\mathrm{L}^{2}\right)_{2}\right]$ and $\left[\mathrm{PhAs}\left(\mathrm{L}^{2}\right)_{2}\right]$ show low MIC values at $10 \mu \mathrm{g} / \mathrm{mL}$ for bacterial strain Bacillus subtilis and at $16 \mu \mathrm{g} / \mathrm{mL}$ for fungal strain Fusarium oxysporum. Metal complexes are more active against fungal strains in comparison to bacterial strains.

The biological activity of the ligands exhibited a marked enhancement on coordination with the metal ions against all the test bacterial/fungal strains which shows that metal chelates are more active than the ligands. This may be explained by Tweedy's chelation theory [19] according to which chelation reduces the polarity of the central metal atom because of the partial sharing of its positive charge with the ligand [20], which favours permeation of the complexes through the lipid layer of cell membrane [21]. Other factors such as solubility, conductivity, and dipole moment which are affected by the presence of metal ions may also be possible reasons for increasing the biological activity of the metal complexes as compared to the corresponding ligands.

The results of antifertility showed that administration of ligands and its metal complexes did not affect the body weights of treated animals. However, a significant reduction was observed in the weights of testes, epididymis, and accessory sex organs (seminal vesicles and ventral prostate) in rats treated with these compounds than those of the control group.

A significant decline in sperm density in testes and epididymis were noticed in rats treated with ligand and its metal complexes. Sperm motility in cauda epididymis was also decreased significantly in experimental animals. Decrease in sperm motility and density could compromise the fertility.

The study revealed a marked reduction in sialic acid and glycogen content in testes. However, testicular cholesterol and protein as well as acid and alkaline phosphatase activity were increased. The levels of serum testosterone were decreased significantly after ligands $\left(\mathrm{L}^{1} \mathrm{H}\right)$ and $\left(\mathrm{L}^{2} \mathrm{H}\right)$ and their $\mathrm{Bi}$ and As complexes.

Our results showed that the weight of testes and accessory sex organs were significantly reduced in rats treated with ligands $\left(\mathrm{L}^{1} \mathrm{H}\right),\left(\mathrm{L}^{2} \mathrm{H}\right)$ and their $\mathrm{Bi}$ and As complexes treated 


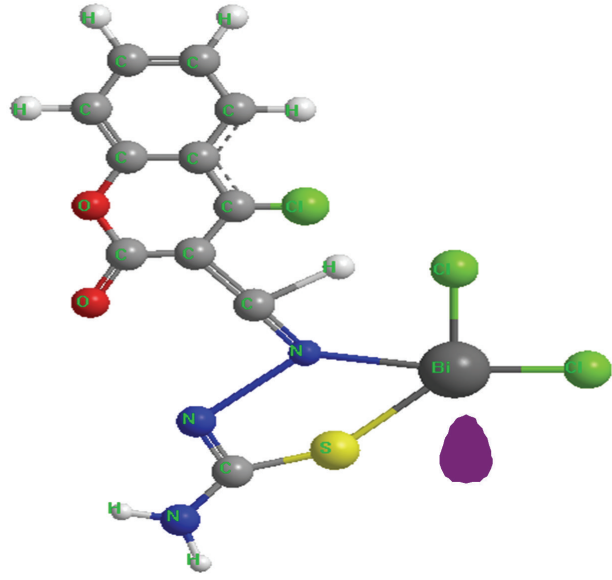

$\left[\mathrm{Cl}_{2} \mathrm{Bi}\left(\mathrm{L}^{1}\right)\right]$

(a)

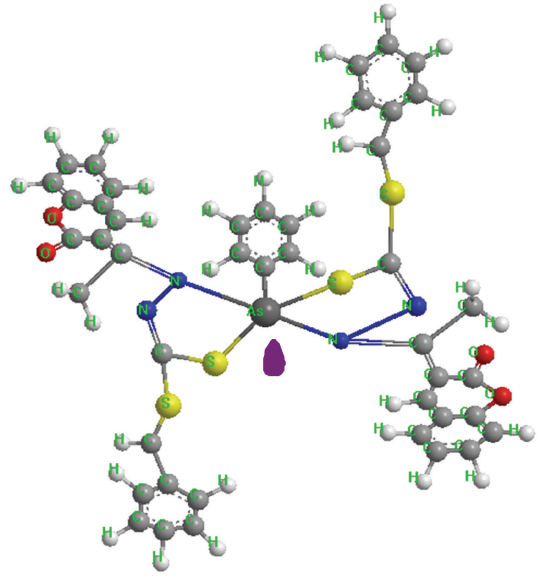

$\left[\operatorname{PhAs}\left(\mathrm{L}^{2}\right)_{2}\right]$

(b)

FIGURE 2: 3-D Molecular structures of the metal complexes.

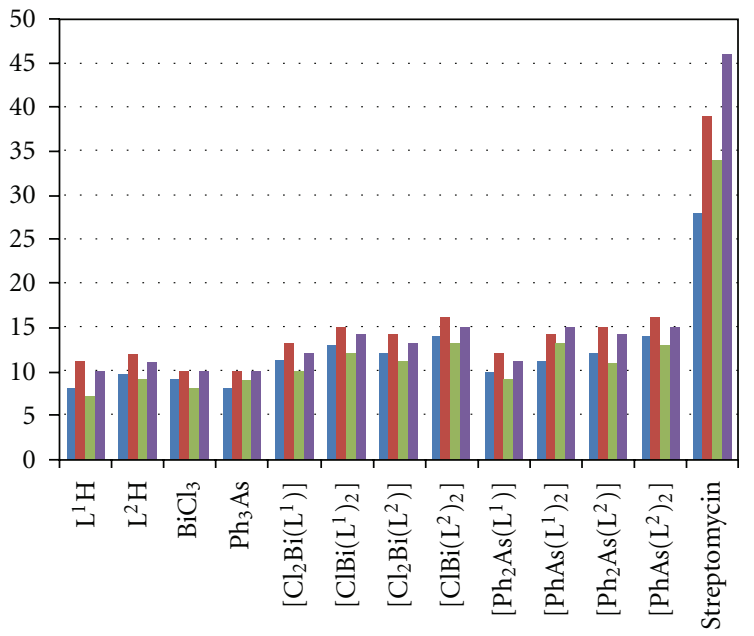

Diameter of inhibition zone (mm) after $24 \mathrm{hr}$ Bacillus subtilis (+) 500

Diameter of inhibition zone (mm) after $24 \mathrm{hr}$ Bacillus subtilis (+) 1000

\footnotetext{
Diameter of inhibition zone (mm) after $24 \mathrm{hr}$ E. coli (-) 500

- Diameter of inhibition zone (mm) after $24 \mathrm{hr}$ E. coli (-) 1000
}

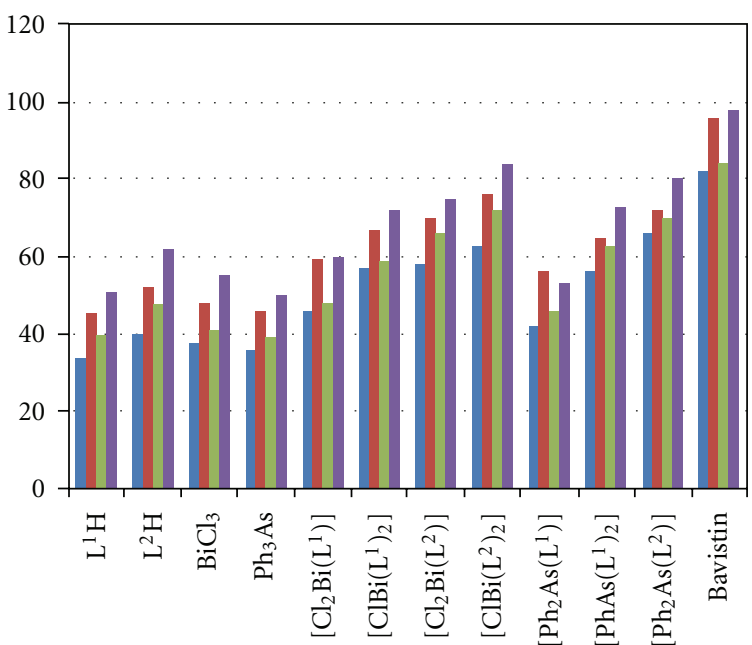

Average \% inhibition after $96 \mathrm{hrs}$ F. oxysporum $100 \mathrm{ppm}$

Average \% inhibition after 96 hrs $R$. nigricans 10 ppm

Average \% inhibition after 96 hrs F. oxysporum 200 ppm

Average \% inhibition after $96 \mathrm{hrs}$ R. nigricans $200 \mathrm{ppm}$

FIgURE 3: Antibacterial screening of the ligands and their complexes.

rats in comparison to control rats. The decreased weight of testes may be due to reduced tubule size spermatogenic arrest and inhibition of steroid biosynthesis of Leydig cells, a site of steroid biosynthesis. The observed reduction in weight of accessory sex organs may be due to antiandrogenic activity of the compounds [22]. Suppression of gonadotropins might have caused decrease in sperm density in testes [23]. The negative fertility test may be attributed to lack of forward progression and reduction in density of spermatozoa and

altered biochemical milieu of cauda epididymis. Ligands $\left(\mathrm{L}^{1} \mathrm{H}\right)$ and $\left(\mathrm{L}^{2} \mathrm{H}\right)$ and their $\mathrm{Bi}(\mathrm{III})$ and $\mathrm{As}(\mathrm{III})$ complexes induces biochemical changes in testes. A significant decrease in testicular sialic acid content in present study indicated the suppressed activity of androgen and gonadotropin. Low levels of sialic acid concentration in treated rats might be due to loss of viability and fertilizing ability of spermatozoa. The elevation in the testicular protein may be due to hepatic detoxification activities caused by these compounds which results in inhibitory effect on the activities of enzymes involved in the androgen biotransformation. A significant increase in testicular cholesterol after ligands $\left(\mathrm{L}^{1} \mathrm{H}\right)$ and 


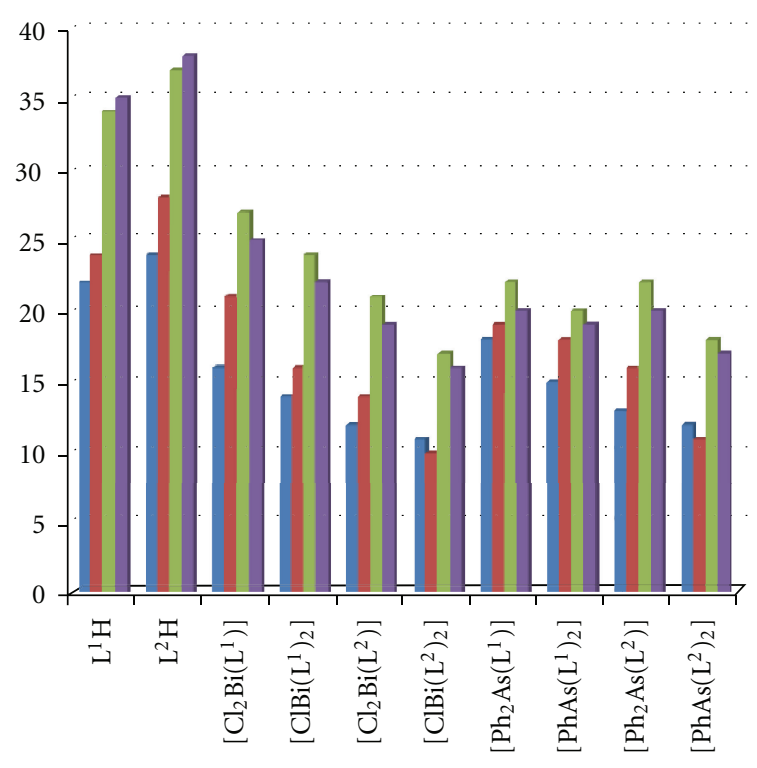

Minimum inhibitory concentration $\mu \mathrm{g} / \mathrm{mL}$ E. coli

- Minimum inhibitory concentration $\mu \mathrm{g} / \mathrm{mL}$ B. subtilis

- Minimum inhibitory concentration $\mu \mathrm{g} / \mathrm{mL}$ Rhizopus nigricans

- Minimum inhibitory concentration $\mu \mathrm{g} / \mathrm{mL}$ F. oxysporum

Figure 5: Minimum inhibitory concentration of the ligands and their complexes.

$\left(\mathrm{L}^{2} \mathrm{H}\right)$ and their $\mathrm{Bi}(\mathrm{III})$ and $\mathrm{As}(\mathrm{III})$ complexes treatment suggests suppressed androgen biosynthesis.

A fall in glycogen levels in testes eventually decreases spermatogenic process [24]. Furthermore, increases in the acid and alkaline phosphatase activity in testes indicate an impairment of functional integrity of the testes.

\section{Conclusion}

We describe the synthesis, characterization, and biological activity of $\mathrm{Bi}(\mathrm{III})$ and $\mathrm{As}(\mathrm{III})$ complexes. On the basis of analytical and spectral data, tetra- and pentacoordinated geometries have been proposed for the Bi(III) and As(III) complexes. The antimicrobial activity results indicated that the complexes showed promising antibacterial and antifungal activities, but compounds $\left[\mathrm{ClBi}\left(\mathrm{L}^{1}\right)_{2}\right]$ and $\left[\mathrm{PhAs}\left(\mathrm{L}^{2}\right)_{2}\right]$ showed highest activity against bacterial strain $B$. subtilis ATCC6633 (MIC $=10 \mu \mathrm{g} / \mathrm{mL})$ and fungal strain F. oxysporum ATCC7808 $(\mathrm{MIC}=16 \mu \mathrm{g} / \mathrm{mL})$. The results suggested that the ligand $\left(\mathrm{L}^{2} \mathrm{H}\right)$ is most effective in reducing fertility, and addition of bismuth and arsenic moiety to this ligand enhanced its activity.

\section{Acknowledgment}

The authors are thankful to the UGC New Delhi for financial assistance through Grant no. 34(324)/SR-I.

\section{References}

[1] A. Kulkarni, P. G. Avaji, G. B. Bagihalli, S. A. Patil, and P. S. Badami, "Synthesis, spectral, electrochemical and biological studies of $\mathrm{Co}(\mathrm{II}), \mathrm{Ni}(\mathrm{II})$ and $\mathrm{Cu}(\mathrm{II})$ complexes with Schiff bases of 8-formyl-7-hydroxy-4-methyl coumarin," Journal of Coordination Chemistry, vol. 62, no. 3, pp. 481-492, 2009.

[2] K. Sharma, R. V. Singh, and N. Fahmi, "Palladium(II) and platinum(II) derivatives of benzothiazoline ligands: synthesis, characterization, antimicrobial and antispermatogenic activity," Spectrochimica Acta Part A, vol. 78, no. 1, pp. 80-87, 2011.

[3] T. S. Basu Baul, "Antimicrobial activity of organotin(IV) compounds," Applied Organometallic Chemistry, vol. 22, pp. 195-204, 2008.

[4] M.-X. Li, J. Zhou, H. Zhao, C.-L. Chen, and J.-P. Wang, "Iron(III) complex of 2-acetylpyrazine thiosemicarbazone: synthesis, spectral characterization, structural studies and antitumoral activity," Journal of Coordination Chemistry, vol. 62, no. 9, pp. 1423-1429, 2009.

[5] D. Shanker, R. K. Sharma, J. Sharma, A. K. Rai, and Y. P. Singh, "Metal-induced rearrangement of benzothiazoline ring: synthesis and characterization of some new organoantimony $(\mathrm{V})$ derivatives of $\mathrm{N}, \mathrm{O}$, and S atom containing Schiff base ligands," Heteroatom Chemistry, vol. 18, no. 1, pp. 70-75, 2007.

[6] K. Singh, D. P. Singh, M. Singh Barwa, P. Tyagi, and Y. Mirza, "Some bivalent metal complexes of Schiff bases containing $\mathrm{N}$ and S donor atoms," Journal of Enzyme Inhibition and Medicinal Chemistry, vol. 21, no. 6, pp. 749-755, 2006.

[7] S. Yadav and R. V. Singh, "Ferrocenyl-substituted Schiff base complexes of boron: synthesis, structural, physico-chemical and biochemical aspects," Spectrochimica Acta Part A, vol. 78, no. 1, pp. 298-306, 2011.

[8] M. Akbar Ali, A. H. Mirza, C. W. Voo, A. L. Tan, and P. V. Bernhardt, "The preparation of zinc(II) and cadmium(II) complexes of the pentadentate $\mathrm{N}_{3} \mathrm{~S}_{2}$ ligand formed from 2,6diacetylpyridine and S-benzyldithiocarbazate ( $\mathrm{H}_{2} \mathrm{SNNNS}$ ) and the X-ray crystal structure of the novel dimeric $\left[\mathrm{Zn}_{2}(\mathrm{SNNNS})_{2}\right]$ complex," Polyhedron, vol. 22, no. 27, pp. 3433-3438, 2003.

[9] H. Sun, H. Li, I. Harvey, and P. J. Sadler, "Interactions of bismuth complexes with metallothionein(II)," Journal of Biological Chemistry, vol. 274, no. 41, pp. 29094-29101, 1999.

[10] R. Karra, Y. P. Singh, and A. K. Rai, "Synthesis and structural elucidation of some new phenylarsenic(III) derivatives of N(-substituted) S-benzyl dithiocarbazates," Phosphorus, Sulfur and Silicon and Related Elements, vol. 166, pp. 125-135, 2000.

[11] A. I. Vogel, A Textbook of Quantitative Chemical Analysis, Pearson Education Ltd.: Thames Polytechnique, London, UK, 6th edition, 2006.

[12] L. Dawara and R. V. Singh, "Synthesis, spectroscopic characterization, antimicrobial, pesticidal and nematicidal activity of some nitrogen-oxygen and nitrogen-sulfur donor coumarins based ligands and their organotin(IV) complexes," Applied Organometallic Chemistry, vol. 25, no. 9, pp. 643-652, 2011.

[13] S. Gaur, N. Fahmi, and R. V. Singh, "Coordination behavior of unsymmetrical ligand complexes of diorganotin and diorganosilicon derived from Schiff bases," Phosphorus, Sulfur and Silicon and the Related Elements, vol. 182, no. 4, pp. 853862, 2007.

[14] S. Shrivastava, N. Fahmi, and R. V. Singh, "Studies on chromium(III) complexes with active nitrogen, oxygen and sulfur donor ketimines synthesized under microwave conditions," Journal of Sulfur Chemistry, vol. 31, no. 6, pp. 515-524, 2010. 
[15] D. Greenwood, R. Slack, and J. Peutherer, Medical Microbiology: A Guide to Microbial Infections: Pathogenesis, Immunity, Laboratory Diagnosis and Control, ELST Publishers, Edinburgh, UK, 15 edition, 1997.

[16] K. Shanker, R. Rohini, V. Ravinder, P. M. Reddy, and Y. P. Ho, "Ru(II) complexes of $\mathrm{N}_{4}$ and $\mathrm{N}_{2} \mathrm{O}_{2}$ macrocyclic Schiff base ligands: their antibacterial and antifungal studies," Spectrochimica Acta Part A, vol. 73, no. 1, pp. 205-211, 2009.

[17] P. M. Davidson and M. E. Parish, "Methods for testing the efficacy of food antimicrobials," Food Technology, vol. 43, no. 1, pp. 148-155, 1989.

[18] C. H. Collins, "Antibiotics and antibacterial substances," in Microbiological Methods, pp. 296-305, Butterworths, London, UK, 1964.

[19] B. Geeta, K. Shravankumar, P. M. Reddy et al., "Binuclear cobalt(II), nickel(II), copper(II) and palladium(II) complexes of a new Schiff-base as ligand: synthesis, structural characterization, and antibacterial activity," Spectrochimica Acta Part A, vol. 77, no. 4, pp. 911-915, 2010.

[20] B. Keshavan and H. Kempe Gowda, "Synthesis, spectral and fungicidal studies on dioxobridged binuclear niobium $(\mathrm{V})$ and tantalum(V) complexes of $\mathrm{N}$-alkylphenothiazines," Turkish Journal of Chemistry, vol. 26, no. 2, pp. 237-243, 2002.

[21] A. W. Varnes, R. B. Dodson, and E. L. Wehry, "Interactions of transition-metal ions with photoexcited states of flavins. Fluorescence quenching studies," Journal of the American Chemical Society, vol. 94, no. 3, pp. 946-950, 1972.

[22] S. C. Joshi, R. Mathur, and N. Gulati, "Testicular toxicity of chlorpyrifos (an organophosphate pesticide) in albino rat," Toxicology and Industrial Health, vol. 23, no. 7, pp. 439-444, 2007.

[23] S. C. Joshi, B. Bansal, and N. D. Jasuja, "Evaluation of reproductive and developmental toxicity of cypermethrin in male albino rats," Toxicological and Environmental Chemistry, vol. 93, no. 3, pp. 593-602, 2011.

[24] B. Desta, "Ethiopian traditional herbal drugs_-part III: antifertility activity of 70 medicinal plants," Journal of Ethnopharmacology, vol. 44, no. 3, pp. 199-209, 1994. 


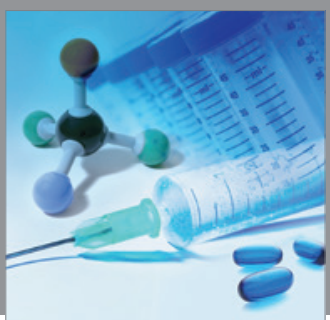

International Journal of

Medicinal Chemistry

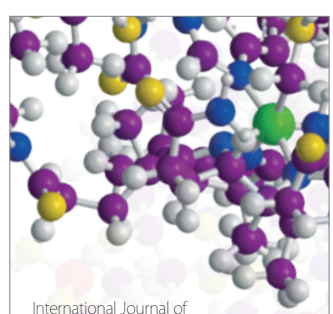

Carbohydrate Chemistry

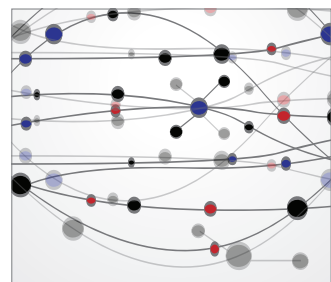

The Scientific World Journal
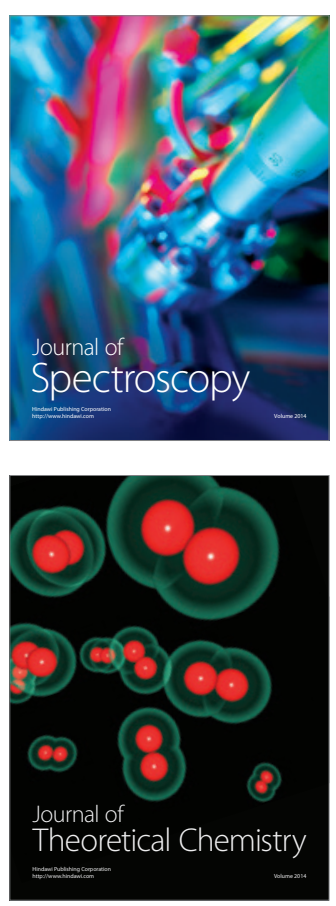
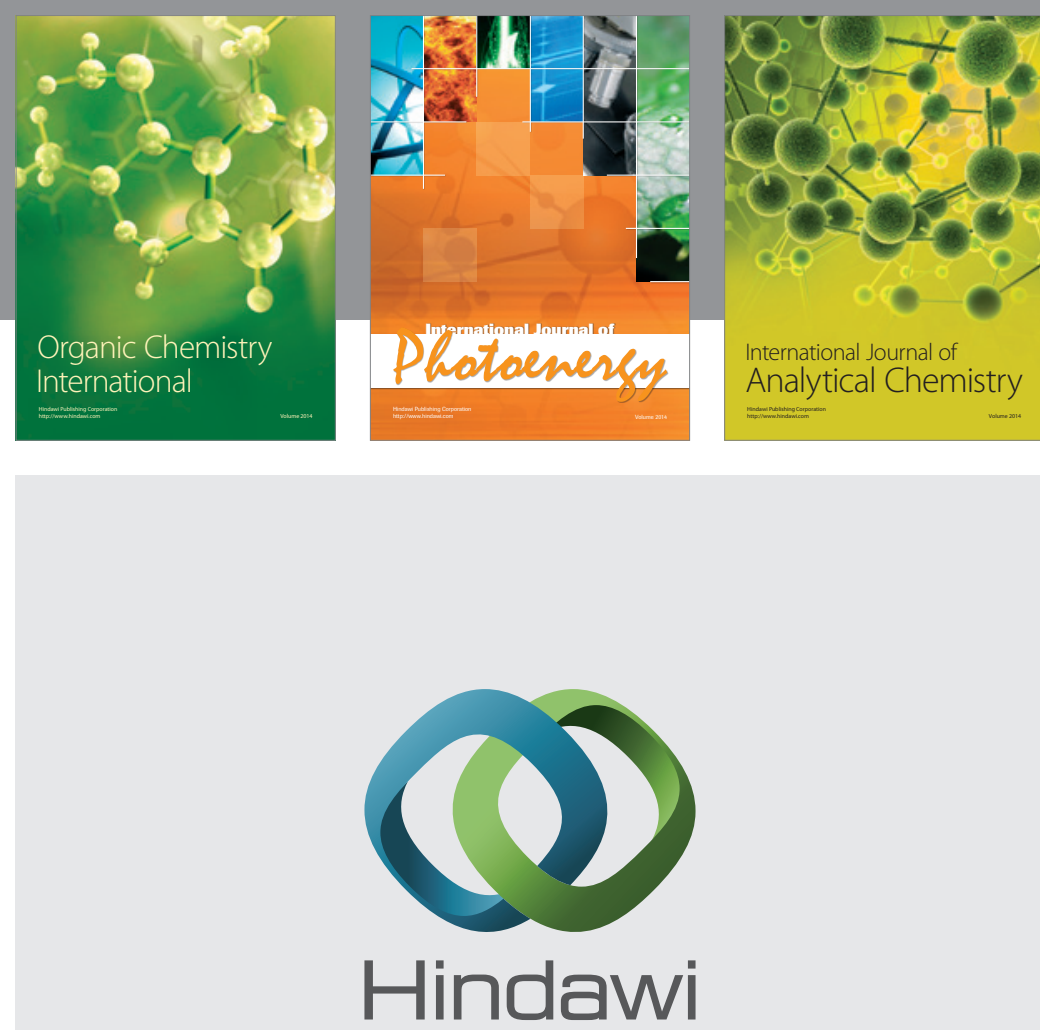

Submit your manuscripts at

http://www.hindawi.com
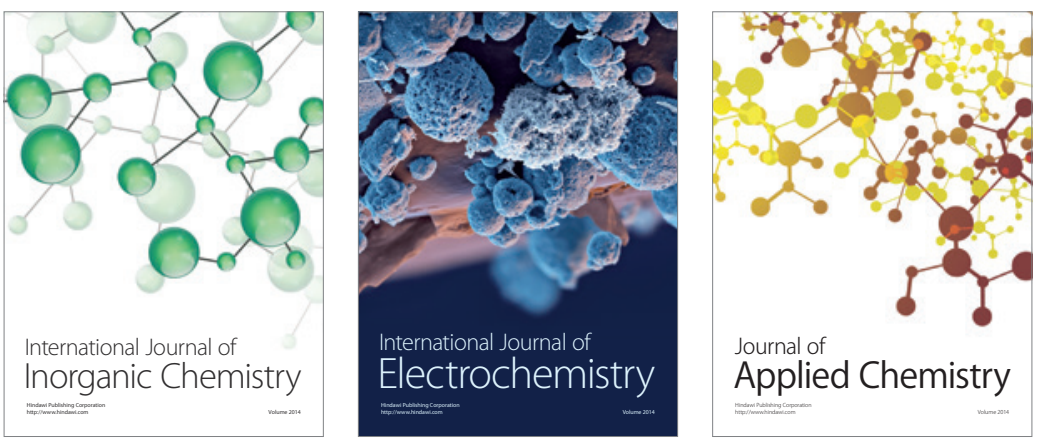

Journal of

Applied Chemistry
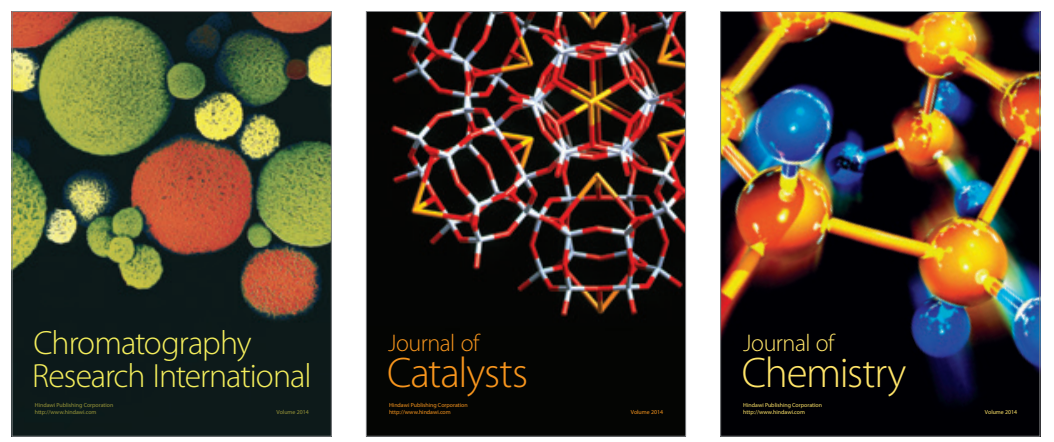
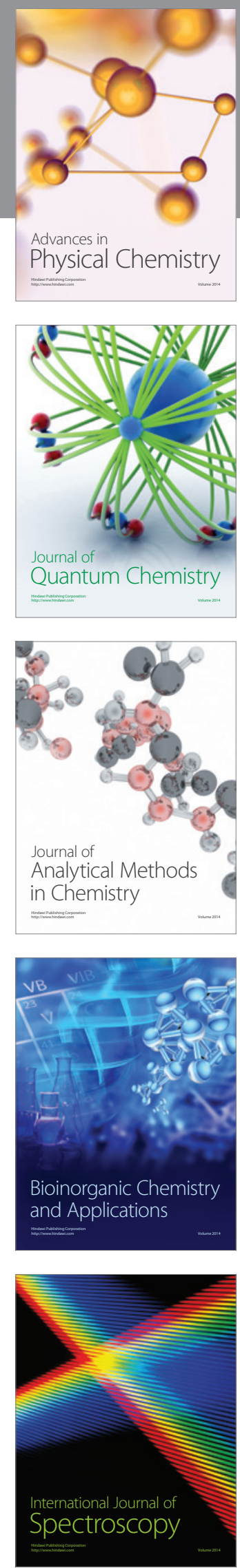